\title{
Corporate Governance and Risk Disclosure: Indonesian Evidence
}

\author{
Ajar Taru Seta ${ }^{1}$, Dyah Setyaningrum ${ }^{1 *}$ \\ ${ }^{1}$ Faculty of Economics and Business, Universitas Indonesia, Depok 16424, Indonesia \\ *dyah.setyaningrum1978@gmail.com
}

\begin{abstract}
This study aims to investigate the effects of ownership structure, composition of board of directors and board of commissioner, and risk policy committees, on risk disclosure. We use 365 samples from Indonesia's publicly listed companies in 2015 and the multiple regression method to test the hypotheses. Using risk category keywords processed by Atlas.ti, the results show that the most common form of risk disclosure is risk as an opportunity, followed by risk as a threat, and risk as an uncertainty. This result indicates that publicly listed companies in Indonesia have the tendency to disclose "good" risk information rather than "bad" risk information. Regarding corporate governance mechanisms, the study finds that ownership concentration has a negative effect on risk disclosure, while government ownership, board size, and risk policy committees have a positive effect on risk disclosure. We also find no significant effect of foreign ownership, independence of directors and commissioners, and gender diversity, on risk disclosure.
\end{abstract}

Keywords: Risk, Risk Disclosure, Ownership Structure, Board of Director, Board of Commissioner, Risk Policy Committee.

\section{INTRODUCTION}

Global corporate financial scandal and global financial crisis in the early 2000s caused a decline in stakeholder trust in published company reports, which has led to a greater demand for increased risk disclosure ${ }^{1}$. Global corporate financial scandal and global financial crisis also reignited the debate on the effectiveness of risk governance and its disclosure to the public ${ }^{1}$. Risk disclosure in Indonesia, in particular, is relatively low compared to other regional countries such as Australia, Malaysia, and Singapore ${ }^{2}$. Thus, Indonesia also needs to improve its risk disclosure practice in order to meet stakeholder expectations regarding the urgency of, and need for, risk information.

Risk disclosure and the definition of risk itself have evolved over time. In this study, risk is defined as the combination of the probability of an event and its consequences, which includes both positive and negative aspects of risk ${ }^{3}$. Furthermore, previous studies have defined risk disclosure as risk information disclosed in a company's annual report. In Indonesia, publicly listed companies are required by regulations and financial reporting standards to disclose risk information in their annual report. However, the regulation does not specifically define the form of risk information that companies should disclose.

Risk disclosure has an impact on a company: A company that discloses risk information will have a better image for investors, as it will provide investors with a better chance to adequately assess a company's risk profile, which ultimately improves decision making to maximize their profits ${ }^{4,5}$. For management, the decision to disclose risk information helps to reduce information asymmetry with stakeholders and maximize the most efficient and effective forms of risk management.

Risk disclosure is affected by the governance mechanisms within the company. The relationship between risk disclosure and governance mechanisms has been previously explored. There is a significant association of ownership concentration, institutional ownership, and government ownership on risk disclosure in South Africa ${ }^{1}$. Another study has found a significant relation between managerial ownership and risk disclosure ${ }^{2}$. Moreover, other governance mechanisms found to have a significant association with risk disclosure are: board size, duality of role of CEO, independence of the board, ethnic and board gender diversity ${ }^{1,5,6}$.

Based on previous risk disclosure studies, we identify some research gaps. First, prior studies mainly focus on developed countries. The risk disclosure studies in developing countries, especially in Indonesia, are relatively few. The fact that Indonesia's regulation still does not specify risk information that should be disclosed by companies, is the motivation for this study. It is important to find out the details of basic risk information disclosed by Indonesian companies. Second, little is known about the impact of ownership structure upon risk disclosure in Indonesia. Third, this study also aims to examine the effects of board independence in a two-tier system on risk disclosure. Fourth, this study also includes specific risk committee as one of the variables to be examined regarding its relation to risk disclosure. This study aims to fill these gaps in risk disclosure, as previously mentioned, using listed companies in Indonesia. 
The remainder of this study proceeds as follows: Section II explains the hypothesis development. Section III discusses the research method, followed by the results and discussion in section IV. Section V concludes the study and provides suggestions for further research.

\section{LITERATURE REVIEW AND HYPOTHESIS DEVELOPMENT Ownership Structures}

The separation between ownership and control creates an agency problem. This problem arises because shareholders, as residual claimants of a company's business activities, will make an effort to secure their interests by influencing management to act in their favor ${ }^{7}$. Concentrated ownership, with the presence of dominant shareholders, will create a disincentive for a company to publicly disclose information because of the low interest of other stakeholders in the company ${ }^{1,8}$. Based on this argument, the first hypothesis of the study is:

H1: Concentrated ownership has a negative effect on risk disclosure

The risk disclosure practice is influenced by the country factor ${ }^{2}$. Foreign ownership will affect disclosure practices, as more diverse shareholders may lead the company to address the problem with disclosing more information ${ }^{9}$. Based on this argument, the second hypothesis of the study is:

H2: $\quad$ Foreign ownership has a positive effect on risk disclosure

Government with the role as governance regulator would encourage companies to perform better in governance and disclosure practices. The government wants to send the signal that it is committed to creating regulations that are congruent with the interests of shareholders. Previous research has found that government ownership has a positive effect on risk disclosure ${ }^{1}$. Based on this argument, the third hypothesis of the study is:

H3: $\quad$ Government ownership has a positive effect on risk disclosure

\section{Board of Director and Board of Commissioner}

The board of directors and board of commissioners are important internal mechanisms within a company to address the problem of agency ${ }^{10}$. The existence of independent commissioners will enhance monitoring, supervision, and disciplinary roles, contributing to good corporate governance ${ }^{1}$. The interests of all stakeholders contain potential risks, and so the board of commissioners that has the role to manage these will choose to disclose risk information to stakeholders ${ }^{2}$. Previous research found a significant positive effect of independent commissioners on risk disclosure ${ }^{1,2}$. Based on this argument, the fourth hypothesis of the study is:

H4: The percentage of independent commissioner has a positive effect on risk disclosure

Independent commissioners will always have to communicate and collaborate with directors towards good corporate governance, because the director is the person who has authority related to managerial management and decision making within the company ${ }^{11}$. The independence of commissioners and independent directors is important to improve risk disclosure ${ }^{5}$. Based on this argument, the fifth hypothesis of the study is:

H5: The percentage of independent director has a positive effect on risk disclosure

Based on agency theory, a larger board size has a positive relation to information disclosed by the company, which reflects good managerial control ${ }^{1}$. However, a smaller board will lead to better coordination, communication, and monitoring ${ }^{12}$. The ASEAN CG Scorecard also states that the size of the board should be sufficient in addressing the needs of business activities, but with the maximum limit to remain effective. Based on this argument, the sixth hypothesis of the study is:

H6: Board size has a positive effect on risk disclosure

Diversity within a company's board may lead to more responsible decisions concerning all stakeholders ${ }^{10}$. This study uses gender diversity as the proxy. The level of gender diversity may also increase independence and managerial control within a company ${ }^{1}$. The ASEAN CG Scorecard also incorporates elements of gender diversity as a factor that improves corporate governance practices, and argues that there is a need for gender diversity in terms of expertise, competence, knowledge and approach, as well as the point of view of the behavior of the board. Based on this argument, the seventh hypothesis of the study is:

H7: $\quad$ Gender diversity has a positive effect on risk disclosure

\section{Risk Policy Committee}

A risk policy committee is a committee that supports the functions of the board of commissioners, specifically on risk issues. Specifically, the committee's responsibilities include monitoring the company's risk profile, gaining an understanding of the company's risk management, and evaluating the risk management (OECD, 2015). As the 
supporting committee under the board of commissioners, this committee also has responsibilities to improve the company's corporate governance practice, which includes the disclosure of information. Based on this argument, the eighth hypothesis of the study is:

H8: The existence of a risk policy committee has a positive effect on risk disclosure

\section{RESEARCH METHOD}

\section{Samples}

The sample consists of 524 companies listed on the Indonesia Stock Exchange (BEI) in 2015 and this comprises the initial population of this study. 89 companies in the financial sector are excluded, since they operate according to different, specific regulations. This study also excludes companies with no full available data of annual report, has a book closing period other than 31 December, and negative equity as of December 31, 2015. This study uses Atlas.ti software for its risk disclosure measurement; therefore, we exclude the companies whose financial reports cannot be processed by this software. Thus, a total of 365 companies constitute the final sample.

\section{Model}

The research model was designed using the regression equation. The model is as follows:

$$
\begin{gathered}
\text { RISK }_{i}=\mathrm{a}_{0}+\beta_{1} \mathrm{OC}_{i}+\beta_{2} \mathrm{FOR}_{i}+\beta_{3} \mathrm{GOV}_{i}+\beta_{4} \text { COMINDP }_{i}+\beta_{5} \text { DIRINDP }_{i}+\beta_{6} \text { BOARDSIZE }_{i}+\beta_{7} \text { DIVERSITY }_{i} \\
+\beta_{8} \text { COMMITTEE }_{i}+\beta_{9} \text { SIZE }_{i}+\beta_{10} \text { ROA }_{i}+\beta_{11} \text { LEV }_{i}+\varepsilon_{i}
\end{gathered}
$$

\section{Content Analysis}

Prior risk disclosure literature applied content analysis to identify risk disclosure. This study uses coding unit of words to identify risk disclosure, as it provides the most accurate comparison to other coding units ${ }^{4}$. The risk disclosure variable in the model will be obtained based on a natural logarithm to produce normal distribution data. In this study, the total risk disclosure is divided based on three risk categories: (1) risk as a threat; (2) risk as an opportunity; and (3) risk as an uncertainty ${ }^{13}$. The difference between this study and previous studies is that the keywords used are translated into Bahasa, as annual reports in Indonesia mainly use Bahasa as their official language.

\section{RESULTS AND DISCUSSIONS Descriptive Statistic Analysis}

Table.1. Descriptive Statistics

\begin{tabular}{lccccc}
\hline \multicolumn{1}{c}{ Variables } & $\mathrm{N}$ & Minimum & Maximum & Mean & $\begin{array}{c}\text { Standard } \\
\text { Deviation }\end{array}$ \\
\hline RISK & 365 & 282 & 2,502 & 743,449 & 348,494 \\
OC & 365 & 0.0661 & 0.9998 & 0.7034 & 0.1773 \\
FOR & 365 & 0 & 0.9841 & 0.2371 & 0.2971 \\
GOV & 365 & 0 & .9003 & 0.0318 & 0.1412 \\
COMINDP & 365 & .25 & 1 & 0.4099 & 0.1051 \\
DIRINDP & 365 & 0 & .75 & 0.2148 & 0.1300 \\
BOARDSIZE & 365 & 4 & 21 & 9.0164 & 3.1158 \\
DIVERSITY & 365 & 0 & .6 & 0.1256 & 0.13065 \\
SIZE (Rp bio) & 365 & 48 & 245,435 & $9,086.077$ & $20,337.65$ \\
ROA & 365 & -0.8293 & 1.8508 & 0.0320 & 0.1643 \\
LEV & 365 & 0.0076 & 16.5394 & 1.4487 & 2.0003 \\
$\quad$ Variable & $\mathrm{N}$ & Value: 0 & $(\%)$ & Value: 1 & $(\%)$ \\
COMMITTEE & 365 & 324 & 88.767 & 41 & 11.233
\end{tabular}

Table I shows the statistic descriptive of this study. We found that the average risk disclosure of Indonesian companies is 743 words, with a range from 282 words to 2,502 words. Indonesian companies also tend to present good news rather than bad, represented by risk information as an opportunity with an average of 371 words, followed by risk information as a threat with an average of 263 words, and risk as an uncertainty with an average of 109 words. This result is also consistent with previous studies which argue that management will choose to avoid disclosing negative risk information because it will have an impact on the company's image ${ }^{1}$. This study also reveals that companies which have a risk policy committee as part of their corporate governance mechanisms disclose more risk information (with an average of 1,203 words, or higher than $61.88 \%$ ) than the average of all companies included in the sample.

Table 2 summarizes the results of regression analysis. The model in this study is statistically significant with Prob $>$ F (f-stat) 0.0000 , and explains $51.78 \%$ of the variation of risk disclosure as its dependent variable.

The regression results reveal a significant negative relationship between ownership concentration and risk disclosure, 
and thus support H1. Consistent with previous research and in line with agency theory, this result suggests that ownership concentration, with the presence of dominant shareholders, minimizes the interests of other stakeholders and thus creates a disincentive for management to disclose information publicly ${ }^{1}$.

There is no association between foreign ownership and risk disclosure, and thus $\mathrm{H} 2$ is rejected. This can be explained by the characteristics of foreign ownership of Indonesian companies. Characteristics of foreign ownership in listed company in Indonesia majority are also included as dominant shareholder (that is, above 5\% ownership). This dominant ownership may lead foreign ownership to act in a way that resembles ownership concentration, which ultimately reduces the incentive to disclose more information ${ }^{8}$.

The regression results reveal a significant positive relationship between government ownership and risk disclosure, and thus support H3. This result suggests that the existence of government ownership is considered to improve the risk information disclosure practices of companies ${ }^{1}$.

Table.2. Regression Analysis Results

\begin{tabular}{lccc}
\hline \multicolumn{1}{c}{ Variables } & Expectations Marks & Coefficient & Significance \\
\hline OC & - & $-0,2442286$ & $0.007^{* * *}$ \\
FOR & + & $-0,0709544$ & 0.1025 \\
GOV & + & 0.6161799 & $0.000^{* * *}$ \\
COMINDP & + & $-0,0943462$ & 0,267 \\
DIRINDP & + & 0,059612 & 0,3405 \\
BOARDSIZE & + & 0,0136687 & $0.022^{* *}$ \\
DIVERSITY & + & $-0,0676571$ & 0,270 \\
COMMITTEE & + & 0,211032 & $0,000^{* * *}$ \\
SIZE & + & 0,1076962 & $0,000^{* * *}$ \\
ROA & + & 0,1411738 & $0,017 * *$ \\
LEV & + & 0,0071687 & 0,1795 \\
\hline
\end{tabular}

Prob > F (F-test) $=0,0000 \mid$ R-squared $=0,5178 \mid \mathrm{N}=365$

OC: ownership concentration | FOR: foreign ownership | GOV: government ownership | COMINDP: percentage of independent commissioner | DIRINDP: percentage of independent director | BOARDSIZE: board size | DIVERSITY: board diversity on the basis of gender |COMMITTEE: dummy variable, the existence of risk policy committee | SIZE: firm's size | ROA: profitability | LEV: leverage | *** significance at $1 \%$. ${ }^{* *}$ significance at $5 \%$. ${ }^{*}$ significance at $10 \%$

In contrast to the framework of agency theory and previous studies, the regression results reveal no association between independent commissioners and risk disclosure, and thus $\mathrm{H} 4$ is rejected. This may be due to the absence of specific regulation of, or guidance on, the commissioner and independent commissioner roles with regards to risk disclosure in Indonesia ${ }^{14}$.

The regression results also reveal a non-significant relationship between independent directors and risk disclosure, and thus reject $\mathrm{H} 5$. Similar to the case of independent commissioners, this result may be explained due to the absence of specific regulation of, or guidance on, the director and independent director roles in connection to risk disclosure in Indonesia.

The regression results reveal a significant positive relationship between board size and risk disclosure, and thus support H6. This result indicates that larger boards have better managerial control, and this positively relates to information disclosed by the company ${ }^{6}$. However, this study also performs a further test on board size, and reveals that a larger board size also indicates a lack of managerial control due to poor coordination, and likely performs less disclosure. This further test also reveals the non-significant relationship of a larger board size to risk disclosure.

In contrast to previous research ${ }^{1}$, the regression results reveal no association between gender diversity and risk disclosure, and thus reject H7. This result may be explained due to the low level of presence of female commissioners or female directors in Indonesian listed companies. Statistic descriptive reveals that the average level of gender diversity is $12.56 \%$, much lower than a previous study that demonstrated an average of $31.46 \%$ gender diversity, with at least one female director or commissioner ${ }^{1}$.

Interestingly, the regression results reveal a significant relationship between the existence of a risk policy committee and risk disclosure, and thus support $H 8$. This result indicates that the role of risk policy committees in Indonesian listed companies can improve good corporate governance and risk disclosure practices for companies.

This regression result shows that a firm's size and profitability is positively significant to risk disclosure, which is consistent with previous studies ${ }^{1,5}$. The results also reveal a non-significant relation between a firm's leverage and risk disclosure ${ }^{8}$. 


\section{CONCLUSIONS}

This study aimed to examine the effects of ownership structure, composition of board of directors and board of commissioners, and risk policy committees, on the risk disclosure practices of publicly listed companies in Indonesia in 2015. This study found that Indonesian companies tend to present risk as good news instead of bad, as the most common form of risk information is risk information as an opportunity, rather than as a threat or uncertainty. The hypothesis testing showed that ownership concentration has a negative effect on risk disclosure, while government ownership, board size, and the existence of a risk policy committee have positive effects on risk disclosure. This study does not provide evidence demonstrating significant impacts on risk disclosure that result from foreign ownership, independent commissioners, independent directors, and gender diversity.

The results of this study have implications for Indonesian regulators. First, we found that the level of compliance from companies in Indonesia still needs to be improved regarding corporate governance mechanisms. Second, this study reveals that companies with a risk policy committee disclose more risk information, which is above the $61 \%$ average for all companies. This can be an alternative input for regulators to conduct mandatory regulation regarding risk policy committees in order to improve risk disclosure practices for all Indonesian companies.

Finally, this study also contains limitations and suggestions for further research. First, the risk disclosure measurement of this study focuses on quantitative disclosure by only categorizing risks as threats, opportunities, or uncertainties. Future research might consider the quality of disclosure by taking into account more comprehensive keywords and categories. Second, the ownership structure variables within this study only use the first level of ownership as their measurement and thus cannot reveal the chain ownership to its basic. Further research could consider the ultimate ownership of the company. Third, directors and commissioners in this study are only measured according to independence and size. Further research could consider the activities and competencies of directors and commissioners. Finally, this study applies a cross-sectional approach to examining risk disclosure practices. Future research could use a longitudinal approach, which would generate a wider understanding of risk disclosure practices in Indonesian companies.

\section{REFERENCES}

[1] C. G. Ntim, S. Lindop, and D. A. Thomas. Corporate governance and risk reporting in South Africa: a study of corporate risk disclosures in pre- and post-2007/2008 global financial crisis periods, International Review of Financial Analysis, 30 (2013) $363-383$.

[2] A. N. Probohudono, G. Tower, and R. Rusmin. Risk disclosure during the global financial crisis, Social Responsibility Journal, 9 (2013) 124-136.

[3] P. M. Collier. Fundamentals of risk management for accountants and managers: tools and techniques 1st edition, 2009.

[4] P. M. Linsley and P. J. Shrives. Risk reporting: a study of risk disclosures in the annual reports of UK companies, The British Accounting Review, 38 (2006) 387-404.

[5] S. Abraham, Santos and P. Cox. Analysing the determinants of narrative risk information in UK FTSE 100 annual reports, The British Accounting Review, 39 (2007) 227-248.

[6] E. S. Mokhtar and H. Mellet. Competition, corporate governance, ownership structure and risk reporting, Managerial Auditing Journal, 28 (2013) 838-865.

[7] E. F. Fama and M. T. Jensen. Separation of ownership and control, Journal of Law and Economics, 26(2) (1983) 301-325.

[8] A. Amran, C. Haat, M. Hassan, and A. M. Rosli. Ownership structure and risk disclosure: a study of Malaysian listed companies, Corporate Ownership and Control, 5 (2008) 37-46.

[9] S. V. Siregar and Y. Bachtiar. Corporate social reporting: empirical evidence from Indonesia Stock Exchange, International Journal of Islamic and Middle Eastern Finance Mangement, 3 (2010) 241-252.

[10] J. A. Fuente, Sanchez, I. M. Garcia, and M. B. Lozano. The role of the board of directors in the adoption of GRI guidelines for the disclosure of CSR information, Journal of Cleaner Production, 141 (2017) 737-750.

[11] Ballesteros, Beatriz Cuadrado, Ariza, Lazaro Rodriguez, and Sanchez, Isabel-Maria Garcia. The role of independent directors at family firms in relation to corporate social responsibility disclosures, International Business Review, 24 (2015) 890-901

[12] M. C. Jensen and W. H. Meckling. Theory of the firm: managerial behavior, agency cost and ownership structure, Journal of Financial Economics, 3 (1976) 305-360.

[13] S. Khaledi. Corporate risk disclosure: a content analysis of Swedish interim reports, Master's Thesis in Accounting, Auditing and Analysis, Uppshala Universiteit, (2014).

[14] S. Vandemele, P. Vergauwen, and A. Michiels. Management risk reporting practices and their determinants: a study of Belgian listed firms, (2009). 